\title{
Possibilidades e desafios no trabalho docente em tempos de pandemia: uma experiência significativa na Faculdade do Nordeste da Bahia
}

\author{
Education work possibilities and challenges in the pandemic times: a \\ significant experience at the \\ Faculdade do Nordeste da Bahia
} Posibilidades y desafíos en el trabajo docente en tiempos de
pandemia: una experiencia significativa en la
Faculdade do Nordeste da Bahia

Jose Batista de Souza'

https://orcid.org/0000-000I-9722-88I8

Daniele Santana de Melo²

https://orcid.org/0000-0003-3727-206I

Suely Cristina Silva Souza ${ }^{3}$

https://orcid.org/0000-0003-I 198-698X

\footnotetext{
' Mestre em Letras pela Universidade Federal de Sergipe - UFS. Professor das Redes Municipal e Estadual da Bahia e da Faculdade do Nordeste da Bahia - FANEB. Membro do Grupo de Pesquisa Educação e Contemporaneidade (EDUCON)/UFS, do Grupo de Estudos e Pesquisas em Formação de Professores e Tecnologias da Informação e Comunicação/FOPTIC/UFS, e do Grupo de Estudos e Pesquisas em Educação Paidéia/FANEB. E-mail. batistinhadesouza@gmail.com

${ }^{2}$ Mestre em Educação pela Universidade Federal de Sergipe - UFS. Professora da Faculdade do Nordeste da Bahia - FANEB. Membro do Grupo de Estudos e Pesquisas em Educação Paidéia/FANEB e do Grupo de Pesquisa e Estudos em Educação Ambiental GEPEASE-UFS/CNPq. E-mail: danieleeli@hotmail.com

${ }^{3}$ Doutora em Educação pela Universidade Federal de Sergipe - UFS. Professora da Faculdade Maurício de Nassau de Aracaju -SE e da Faculdade do Nordeste da Bahia- FANEB. Membro do Grupo de Estudos e Pesquisas em Educação Paidéia/FANEB e do Grupo de Pesquisa Disciplinas Escolares: História, Ensino e Aprendizagem (DEHEA/UFS/CNPq), do Instituto Histórico e Geográfico de Sergipe. E-mail: suelycss35@yahoo.com.br.
}

Olhar de professor, Ponta Grossa, v. 24, p. I-25, e-I5952.04I, 2021.

Disponível em <https://revistas2.uepg.br/index.php/olhardeprofessor> 
Possibilidades e desafios no trabalho docente em tempos de pandemia: uma experiência significativa...

Resumo: A pandemia da Covid-19 tem sido alvo de preocupações de diversos setores sociais, a exemplo da educação. Assim, este trabalho tem como objetivo mostrar como a Faculdade do Nordeste da Bahia tem se reinventado para superar as barreiras do distanciamento físico e a criatividade do seu corpo docente para ofertar aos licenciandos um processo formativo mais qualificado até o retorno das aulas presenciais. Trata-se de uma pesquisa qualitativa, envolvendo professores do curso de Pedagogia, no período de 26 de março a 10 de junho de 2020. O aporte teórico utilizado conta com Moran (2003), Santos (2005), Schlemmer e Moreira (2020), Silva (2008), Silveira (200I), entre outros. Apesar de preliminares, os resultados têm apontado a criatividade dos professores e uma preocupação maior com o uso das Tecnologias Digitais de Informação e Comunicação - TDIC em favor do ensino.

Palavras-chave: Distanciamento Físico. Educação. Pandemia.

Abstract: The COVID-19 pandemic has been a target of concern for several social sectors, such as education. Thus, this work aims to show how Faculdade do Nordeste da Bahia has reinvented itself to overcome the barriers of physical distance and the creativity of its professors to offer licensors a more qualified training process until the return of the presential classes. This is a qualitative research involving teachers from the Pedagogy course, from March 26 to June 10, 2020. The theoretical framework used includes Moran (2003), Santos (2005), Schlemmer and Moreira (2020), Silva (2008), Silveira (200I), among others. Despite being preliminary, the results have pointed to the creativity of professors and a greater concern for the use of Digital Information and Communication Technologies - TDIC in favor of teaching.

Keywords: Physical Distance. Education. Pandemic.

Resumen: La pandemia de COVID-19 ha sido un objetivo de preocupación para varios sectores sociales, como la educación. Por lo tanto, este trabajo tiene como objetivo mostrar cómo la Faculdade do Nordeste da Bahia se ha reinventado para superar las barreras de la distancia física y la creatividad de su profesores para ofrecer a los licenciatarios un proceso de formación más calificado hasta el regreso del aula. Esta es una investigación cualitativa que involucra a maestros del curso de Pedagogía, del 26 de marzo al 10 de junio de 2020. El La contribución teórica utilizada incluye Moran (2003), Santos (2005), Schlemmer y Moreira (2020), Silva (2008), Silveira (200I), entre otros. Aunque preliminares, los resultados han señalado la creatividad de los docentes y una mayor preocupación con el uso de Tecnologías Digitales de Información y Comunicación - TDIC a favor de la enseñanza

Palabras-clave: Distancia física. Educación. Pandemia.

\section{Introdução}

Nos últimos meses, um surto pandêmico, iniciado na China no final de 2019, tem atingido o mundo, desestruturando as bases de todos os setores da sociedade, obrigando as pessoas a permanecerem em suas casas e a tomarem medidas de segurança eficazes para evitar a contaminação. Segundo o Ministério da Saúde (BRASIL, 2020), o surto é tem sido pela Covid-19, uma doença causada pelo coronavírus SARS-CoV-2 ${ }^{4}$, cujo quadro clínico apresenta desde quadros de infecções assintomáticos a problemas respiratórios graves. A sigla Covid vem do inglês corona vírus disease (doença do coronavírus). Quanto ao número 19, diz respeito ao ano em que o vírus foi detectado na China 2019 (FIOCRUZ, 2020). Em diferentes momentos da história, alguns surtos pandêmicos marcaram milhares de vítimas, a exemplo da peste negra, da varíola, da gripe espanhola e da gripe suína, esta última a mais recente, há pouco mais de uma década (RODRIGUES, 2020).

\footnotetext{
${ }^{4}$ Segunda espécie de vírus, de uma família de sete, que pode produzir doenças graves, por isso o número 2. Disponível em: https://pfarma.com.br/coronavirus/5439-origem-covid I9.html. Acesso em: I2 dez. 2020.
}

Olhar de professor, Ponta Grossa, v. 24, p. I-25, e-15952.04I, 2021.

Disponível em <https://revistas2.uepg.br/index.php/olhardeprofessor> 
Jose Batista de Souza, Daniele Santana de Melo e Suely Cristina Silva Souza

Diante da pandemia de Covid-19, instaurou-se um contexto de adversidades globais, que fez com que os setores analisassem a necessidade de reinvenção para continuar a oferecer seus serviços e evitar a estagnação total da economia. A problemática é tão complexa que tem trazido, mesmo em poucos meses, consequências bastante significativas para a vida social, afetando as pessoas diretamente em suas relações com o trabalho, a família, os negócios, a educação, entre outros. O desafio é grande para todos e, no momento, criatividade é o lema para seguir em frente.

Especificamente no contexto educacional brasileiro, os problemas são gigantescos. As aulas foram temporariamente suspensas em março, por determinação do Ministério da Educação - MEC, mas, de lá para cá, devido ao índice crescente de mortes e de novas vítimas do coronavírus, novas prorrogações têm sido feitas, o que aponta para um cenário de incertezas em relação à continuidade do ano letivo de 2020 e também 2021.

Em meio a suspensões, necessidade de clausura e preocupações com os rumos da educação, diversas instituições de ensino públicas e privadas têm usado as orientações do MEC e a criatividade para continuar suas funções, mesmo a distância ${ }^{5}$, fazendo uso de tecnologias digitais diversas para seguir adiante, a exemplo da UFMS, UNIFEI, UFSM, UFC, UFFS e UFABAC, que adotaram a plataforma disponibilizada pelo Ministério da Educação (MEC) para ministrar aulas remotamente (ARAÚJO, 2020).

Assim, a Covid-19, além de afetar a saúde de milhares de pessoas, tem afetado também a educação, requerendo adaptação ao trabalho com ferramentas digitais e às novas formas de ensinar, aprender, interagir e construir conhecimento, algo que, provavelmente, após a pandemia, dará outros rumos à educação.

Algumas instituições estão trabalhando com a educação a distância, modalidade bastante conhecida e amparada pela Lei de Diretrizes e Bases da Educação - LDB 9.394/96 (BRASIL, 2019), através de plataformas específicas para esse tipo de educação, a exemplo de AVAs (ambientes virtuais de aprendizagem) e Moodles. Outras atuam com o ensino remoto, fazendo o uso de diferentes tecnologias móveis. Através do envio de atividades para os alunos por meio de tecnologias digitais diversas, e de aulas via de diferentes aplicativos, a exemplo do Google Meet (videoconferência), muitas instituições de ensino tentam manter os alunos focados nos estudos, de modo que eles não tenham seu processo de aprendizagem interrompido 6 . $O$ ensino remoto se dá pela emergência da situação, com o aval do MEC.

Ainda há, nesse contexto, discussões sobre educação online, a qual é totalmente voltada para a interação professor/aluno via tecnologias digitais, notadamente marcada pela interatividade e

\footnotetext{
${ }^{5}$ Neste texto, a expressão "a distância”, não precedida pela palavra "educação", refere-se especificamente ao distanciamento físico que o período de pandemia exige.

${ }^{6}$ A Faculdade do Nordeste da Bahia se insere neste contexto.
}

Olhar de professor, Ponta Grossa, v. 24, p. I-25, e-15952.04I, 202 I.

Disponível em <https://revistas2.uepg.br/index.php/olhardeprofessor> 
Possibilidades e desafios no trabalho docente em tempos de pandemia: uma experiência significativa... construção colaborativa do conhecimento, possibilitada por diferentes interfaces específicas da cibercultura. Ou seja, uma nova forma de educação, diferente do ensino presencial, da educação a distância e do ensino remoto. Algo mais sólido, com o uso de tecnologias digitais, mas que precisa de mais investimento e mudanças de paradigmas educacionais (SANTOS, 2005; SCHLEMMER; MOREIRA, 2020).

Frente a este cenário, surge o seguinte questionamento: Como superar os desafios impostos pela pandemia e manter a qualidade do ensino na Faculdade do Nordeste da Bahia - FANEB através do ensino remoto?

Com base neste questionamento, o objetivo do trabalho é mostrar como a FANEB tem se reinventado para superar as barreiras do distanciamento físico e a criatividade do seu corpo docente para oferecer aos educandos um ensino remoto de qualidade até o retorno das aulas presenciais.

Para tanto, apresentamos a experiência da FANEB, através da qual os professores destacam suas impressões acerca do ensino remoto, abordando pontos positivos e negativos em relação ao trabalho no contexto em foco e todos os desafios que se impuseram e se impõem até o momento na empreitada.

Apesar de preliminares, os resultados apontam que, mesmo com as dificuldades de acesso à internet (algo que mais se destacou ao longo da pesquisa) e de alguns equívocos por parte dos estudantes em relação à educação a distância e ensino remoto, este último tem trazido bons resultados, a exemplo da interação professor/aluno, da desenvoltura dos alunos com as tecnologias digitais e de um certo protagonismo discente.

O trabalho apresenta a seguinte configuração: na primeira seção, que segue a introdução, trazemos uma discussão acerca da pandemia e de como ela tem afetado a educação, e discutimos sobre os desafios de pais e alunos em relação à falta de condições materiais e de acesso às tecnologias digitais, enfatizando, à luz de alguns teóricos, a questão da exclusão digital como um dos elemento da exclusão social. $\mathrm{Na}$ seção seguinte, delineamos uma discussão sobre educação a distância, ensino remoto e educação online, mostrando suas terminologias conceituais e desfazendo, à luz da literatura, alguns equívocos perceptíveis no contexto atual. Na seção posterior, expomos o desenho metodológico do trabalho, enfatizando a experiência da Faculdade do Nordeste da Bahia com o ensino remoto. Na última seção, apresentamos as considerações finais, momento no qual retomamos os principais aspectos do trabalho.

\section{Como a pandemia da Covid-1 9 tem afetado a educação}

Desde o mês de março, quando instituições públicas e privadas de ensino de todos os níveis educacionais suspenderam, em parte ou totalmente, suas atividades presenciais, por orientação do 
Jose Batista de Souza, Daniele Santana de Melo e Suely Cristina Silva Souza

Ministério da Educação, em virtude da problemática acarretada pela pandemia da Covid-19, aumentaram-se os desafios para levar adiante o processo de ensino-aprendizagem sem interrupção do ano letivo. Isso tem gerado diversas preocupações, tanto por parte das instituições como dos alunos e de suas famílias, o que leva a todos a uma sensação de insegurança e de vontade de voltar o mais rápido possível à "normalidade".

Por conta deste cenário, e a fim de mitigar o efeito do distanciamento social no aprendizado dos alunos, inúmeras instituições de ensino, nos diferentes estados brasileiros, amparadas por suas secretarias, e com o aval do MEC, estão empreendendo esforços para não parar suas funções, fazendo uso da criatividade para conseguir levar ensino e aprendizagem aos alunos. Através das tecnologias digitais, professores utilizam diferentes meios para continuar o processo educativo, mesmo a distância, na tentativa de não se afastar dos alunos e de orientá-los para que eles não tenham seu processo de aprendizagem interrompido (TODOS PELA EDUCAÇÃO, 2020; CONSED, 2020).

Sabemos que a contaminação tem aumentado a passos largos em todo o mundo, diariamente, por isso a preocupação com a saúde e a atitude do distanciamento social são fundamentais e devem ser vistos como a decisão mais acertada, cabendo à escola continuar buscando alternativas para continuar com o processo educativo e, ao mesmo tempo, preservar a saúde dos seus alunos. Entretanto, há também a necessidade de investimento de esforços, por parte dos organismos políticos-educativos que gerenciam a educação pública, propiciando suporte e auxílio para que as escolas e os professores desenvolvam um trabalho mais direcionado às necessidades dos estudantes e do contexto com o qual interagem. Além disso, a sociedade também precisa fazer sua parte, tomando todos os cuidados necessários e ajudando a escola no que for possível.

Tal preocupação é importante porque precisamos, de fato, manter o isolamento social, a fim de evitar uma contaminação em massa. Essa atitude é bastante relevante para a diminuição da taxa diária de transmissão e para o achatamento da curva de contaminação, pois quanto mais pessoas contaminadas em um curto período de tempo, maior é a tendência do sistema de saúde entrar em colapso, conforme sinaliza a Organização Mundial da Saúde - OMS (CRESCER, 2020; QUEIROZ, 2020).

Assim, as instituições de ensino precisam usar a criatividade para manter uma proximidade com os alunos mediante as tecnologias digitais, conduta importante, dentre tantos fatores, porque evitará deixar os alunos, principalmente os mais vulneráveis, expostos a situações adversas. Além disso, o fechamento das escolas e o não comprometimento com a continuação do processo educativo podem prejudicar decisivamente o processo de ensino-aprendizagem dos alunos.

Não obstante a iniciativa de continuar o processo educativo remotamente, os desafios pelos quais as famílias e os alunos têm passado são enormes. Muitos são os depoimentos de pais e alunos acerca das dificuldades de lidar com o cenário e das angústias vividas neste período (PORTAL BONDE,

Olhar de professor, Ponta Grossa, v. 24, p. I-25, e-15952.04I, 202 I.

Disponível em <https://revistas2.uepg.br/index.php/olhardeprofessor> 
Possibilidades e desafios no trabalho docente em tempos de pandemia: uma experiência significativa...

2020; SAMPAIO, 2020). Desse modo, o ensino remoto, mediado pelo uso das tecnologias, pode configurar uma via efetiva de desenvolvimento do processo de ensino e aprendizagem, mas requer o diálogo e engajamento de todos os envolvidos no processo.

Além disso, há problemas mais preocupantes, como é o caso de milhares de alunos sem acesso a tecnologias digitais e que, portanto, não estão inseridos no contexto de aulas a distância, já que não dispõem dos recursos necessários (computador, notebook, tablet ou smartphone). E daqueles que possuem algumas ferramentas, grande parte não dispõem de internet para se manter online e dar conta das aulas e atividades organizadas pelos professores (VALADARES, 2020). Assim, "a exclusão digital é um novo segmento da exclusão social mais ampla. Um desafio político!” (SANTOS, 2005, p. 105).

Nesse viés, a exclusão digital ocorre porque as famílias com baixo poder aquisitivo não têm condições de comprar computador, tablet ou celular para os seus filhos estudarem, nem de pacote de internet suficiente para que eles estudem online.Assim, no contexto escolar, os alunos das classes mais desfavorecidas da sociedade não terão as mesmas condições de estudo que alunos oriundos das classes média e alta, o que contribuirá para o aumento da exclusão social mais ampla.

As novas tecnologias e os frutos da revolução tecnológica tendem a ampliar o distanciamento entre ricos e pobres. [...]. Enquanto um jovem das camadas abastadas da sociedade tem acesso ao ciberespaço e a todas as fontes de informação disponíveis em bilhões de sites espalhados pelo globo, o adolescente das camadas pauperizadas fica privado de interagir com os produtores de conteúdo, de observá-los, de questioná-los, de copiar seus arquivos. Para a pessoa incluída na rede, a navegação estimula a criatividade, permite realizar pesquisas sobre inúmeros temas e encontrar com maior velocidade o resultado de sua busca. Quem está desconectado desconhece o oceano informacional, ficando impossibilitado de encontrar uma informação básica, de descobrir novos temas, de despertar para novos interesses (SILVEIRA, 200I, p. 16-17).

Infelizmente, tal realidade já existia, mas com a pandemia em ação, as desigualdades sociais ficaram ainda mais evidenciadas. Assim, as mesmas pessoas que em outras épocas foram privadas de bens básicos, como alimentação, saneamento básico, saúde e educação, hoje continuam sendo vítimas do mundo digital, já que, em muitos casos, não possuem aparelhos, nem acesso à internet. Ou seja, as desigualdades sociais existentes entre os alunos no Brasil é algo bastante notório e, quando voltamos nosso olhar para $\circ$ acesso às tecnologias digitais, as desigualdades aumentam, o que contribui para $\circ$ aumento da exclusão digital, que ganha contornos diferentes de região para região (ARAÚJO; MATTOS, 2018).

Segundo pesquisa divulgada recentemente pela Agência Brasil, I em cada 4 brasileiros não tem acesso à internet e, de modo geral, 46 milhões não acessam a rede (TOKARNIA, 2020). Segundo a Organização das Nações Unidas (ONU), a internet é uma questão de direitos humanos. Em outras palavras, num mundo movido pelas tecnologias digitais, ninguém pode ser privado de usufruir deste 
Jose Batista de Souza, Daniele Santana de Melo e Suely Cristina Silva Souza

bem tão importante, sob o risco de perder diversas oportunidades e de ter seu campo de possibilidades reduzido, razão pela qual há que se ter uma política de acesso à internet democratizada em todo o mundo e, especialmente, no Brasil, onde as desigualdades relativas a acesso à internet são bastante precárias (NAÇÕES UNIDAS BRASIL, 2016).

A exclusão digital ocorre ao se privar as pessoas de três instrumentos básicos: o computador, a linha telefônica e o provedor de acesso. $O$ resultado disso é o analfabetismo digital, a pobreza e a lentidão comunicativa, o isolamento e o impedimento do exercício da inteligência coletiva. Esses três resultados podem ser comparados aos estragos que a fome gera nos primeiros anos de vida de uma criança (SILVEIRA, 200I, p. I8).

A linha de raciocínio de Silveira (2001), para além de uma real constatação do cenário no qual nos encontramos quando o assunto são tecnologias digitais e acesso à internet, é uma denúncia, pois privar o sujeito de bens básicos chega a ser desumano, tendo em vista que a própria ONU apontou a internet como um direito humano. Assim, é preciso que atitudes governamentais sejam tomadas urgentemente, para que as camadas mais pobres da população não sejam mais uma vez prejudicadas.

De fato, a preocupação com o acesso às tecnologias digitais para continuar estudando nesse momento de pandemia é uma realidade no Brasil. Há muito o que ser feito para lidar com a problemática, mudando-se a realidade contemporânea e investindo-se significativamente em educação, como fazem países como a China, por exemplo, que neste momento tem cerca de 240 milhões de alunos estudando em casa via tecnologias digitais, desde a educação básica ao ensino superior, mostrando ao mundo que, com organização e investimento maciço em educação, é possível fechar as salas de aula sem parar de aprender (CUNHA, 2020).

\section{Educação a distância, ensino remoto e educação online}

Neste cenário pandêmico, muitas são as alternativas utilizadas pelas diferentes instituições de ensino em todo o Brasil, desde a educação básica ao ensino superior. Há algo em comum em suas ações - o uso de tecnologias digitais variadas, na tentativa de não perder de vista o aluno e de prosseguir com o processo de ensino-aprendizagem.

Algumas instituições têm optado pela educação a distância, uma modalidade de ensino bastante antiga, inclusive com amparo legal da Lei de Diretrizes e Bases da Educação Nacional - LDB 9.394/96, especialmente em seu Art. 80, quando sinaliza que "o Poder Público incentivará o desenvolvimento e a veiculação de programas de ensino a distância, em todos os níveis e modalidades de ensino, e de educação continuada" (BRASIL, 1996, p. 5I).

Não se trata de algo novo no Brasil, apesar do cenário notadamente marcado pela crise pandêmica apontar para isso. A educação a distância é uma modalidade de ensino utilizada no mundo

Olhar de professor, Ponta Grossa, v. 24, p. I-25, e-15952.04I, 202 I.

Disponível em <https://revistas2.uepg.br/index.php/olhardeprofessor> 
Possibilidades e desafios no trabalho docente em tempos de pandemia: uma experiência significativa...

desde I850, e que daquele período até os dias atuais, passou por várias gerações, começando via papel impresso e continuando com o rádio e a televisão ( ${ }^{\mathrm{a}}$ geração: 1850 a 1960); fitas de áudio e vídeo,TV, fax e papel ( $2^{\mathrm{a}}$ geração: 1960 a 1985); correio eletrônico, papel impresso, computadores, internet, $C D$, videoconferência e fax ( $3^{\mathrm{a}}$ geração: 1985 a 1995); correio eletrônico, chat, computador, internet, transmissões em banda larga, interação por vídeo e ao vivo, videoconferência, fax, papel impresso ( $4^{\mathrm{a}}$ geração: 1995-2005); o que já era oferecido na quarta geração mais a comunicação via computadores com sistema de respostas automatizadas, além de acesso via portal a processos institucionais $\left(5^{a}\right.$ geração: atual) ${ }^{7}$.

Houve uma grande evolução na modalidade de educação a distância para se chegar à forma que é hoje, visto que seu início começou com o papel, até o computador conectado à internet, possibilitando uma educação massiva, já que seu formato atende, ao mesmo tempo, milhares de alunos. Esse tipo de educação, durante muito tempo, foi marcado por seu caráter instrucionista, modificando-se com o passar do tempo por causa das exigências que os novos cenários exigem, isto é, uma educação na qual, apesar da distância física que separa professores e alunos, haja o mínimo de interação.

[...] a modalidade a distância privilegia pedagogicamente os conceitos de "autoaprendizagem" e "auto-estudo". O sujeito interage com o material e aprende por esta mediação.A aprendizagem colaborativa não é vivenciada pelo aprendente. Neste modelo a qualidade dos processos é centrada no desenho didático ou instrucional, geralmente instrucionistas. $A$ interação social, quando acontece, é de um para um, ou seja, professor/aluno - aluno/professor. O que podemos ter - se o material for bem escrito e desenhado - é a interação com o texto do autor. Interação pode até existir, mas interatividade não é possível com a mediação das mídias de massa (SANTOS, 2009, p. 5668).

Trata-se de um tipo de educação que não favorece efetivamente a interação entre alunos e professores, pois os únicos parceiros dos alunos, com quem eles podem de alguma forma interagir, são os livros e demais materiais de que fazem uso. Esta modalidade educacional, apesar de contribuir para a organização e autonomia do aluno, já que ele precisará criar uma rotina própria de estudos e seguir os cronogramas previamente organizados, acaba, por outro lado, contribuindo para um aluno menos comunicativo do ponto de vista da oralidade. É notório que muitos alunos aprendem mais quando participam de discussões ativamente, quando são ouvidos, quando podem questionar, discordar, concordar, ampliar linhas de raciocínio, algo que a educação a distância está longe de possibilitar.

Assim, no período de pandemia, para as instituições que já trabalhavam com a modalidade de educação a distância praticamente não houve impacto. Mas algumas instituições de ensino presencial, a exemplo da FANEB, locus desta pesquisa, precisaram se reinventar para continuar seus trabalhos,

\footnotetext{
7 Disponível em: https://siteantigo.portaleducacao.com.br/conteudo/artigos/educacao/geracoes-da-educacao-adistancia/50367. Acesso em: 25 maio 2020.
}

Olhar de professor, Ponta Grossa, v. 24, p. I-25, e-I5952.04I, 202 I.

Disponível em <https://revistas2.uepg.br/index.php/olhardeprofessor> 
adotando diferentes estratégias para não interromper o ano letivo, fazendo o uso de um ensino a distância, amparado pelo Ministério da Educação através das portarias $343^{8}$ e 3459, que autorizam instituições de educação superior públicas e privadas, em caráter excepcional, substituir disciplinas presenciais por diferentes tipos de aulas que façam uso de tecnologias digitais.

No entanto, vale frisar que, segundo as referidas portarias, cada instituição precisa definir, junto ao MEC, suas metodologias e infraestrutura de tecnologia, de modo que garantam aos estudantes uma continuação dos estudos com qualidade. É preciso demonstrar condições de prosseguir com os trabalhos no novo formato para que as aulas sejam validadas e não alvo de contestação por parte dos alunos.

Na Faculdade do Nordeste da Bahia, incialmente, foram utilizadas diferentes tecnologias digitais (Whatsapp, Instagram, Facebook, Youtube, Padlet, Podcast, Skype, entre outras) e, após algum tempo, a instituição adotou o Google Meet como tecnologia base, apesar de as anteriores continuarem sendo usadas como suporte no processo de ensino-aprendizagem.

Faz-se mister salientar que as referidas portarias do MEC não dão abertura para as instituições migrarem do ensino presencial para a educação a distância, a partir de desenhos de aprendizagem instrucionais e de educação massiva. As portarias são bem claras ao especificar a abertura dado o caráter excepcional e emergencial no qual nos encontramos, sendo o ensino remoto a alternativa mais adequada no momento.

O ensino presencial físico (mesmos cursos, currículo, metodologias e práticas pedagógicas) é transposto para os meios digitais, em rede. O processo é centrado no conteúdo, que é ministrado pelo mesmo professor da aula presencial física. Embora haja um distanciamento geográfico, privilegia-se o compartilhamento de um mesmo tempo, ou seja, a aula ocorre num tempo síncrono, seguindo princípios do ensino presencial. A comunicação é predominantemente bidirecional, do tipo um para muitos, no qual o professor protagoniza vídeo-aula ou realiza uma aula expositiva por meio de sistemas de webconferência. Dessa forma, a presença física do professor e do aluno no espaço da sala de aula geográfica são substituídas por uma presença digital numa sala de aula digital. No ensino remoto ou aula remota o foco está nas informações e nas formas de transmissão dessas informações. A lógica que predomina é a do controle, tudo o que é concebido e disponibilizado é registrado, gravado e pode ser acessado e revisto posteriormente (SCHLEMMER; MOREIRA, 2020, p. 9).

Assim, é preciso que fique claro que o ensino remoto não se resume a plataformas de aula online com a postagem de vídeos e diferentes documentos e atividades. Trata-se de uma experiência de ensino que permite ao professor diversificar as formas de ensino e aprendizagem. Além disso, não se trata de um tipo de ensino no qual o aluno deva sozinho operacionalizar as plataformas online, pois o

8 Disponível em: <http://www.in.gov.br/en/web/dou/-/portaria-n-343-de-I7-de-marco-de-2020-248564376>. Acesso em: 5 jun. 2020.

${ }^{9}$ Disponível em: <https://www.legisweb.com.br/legislacao/?id=390992 >. Acesso em: 5 jun. 2020. 
Possibilidades e desafios no trabalho docente em tempos de pandemia: uma experiência significativa...

professor continua sendo o elo entre o aluno e a aprendizagem, como o mediador do processo, sendo as tecnologias digitais apenas o meio para essa mediação. Não importa a distância física que separa professor e alunos, a atuação do primeiro continua sendo central no processo e, por mais ricas que sejam, as tecnologias digitais por elas mesmas não darão conta de substituir o professor (TODOS PELA EDUCAÇÃO, 2020).

Em grande parte dos cursos via internet prevalece o modelo comunicacional centrado na transmissão de informações. Os ambientes "virtuais" de aprendizagem continuam estáticos, ainda centrados na distribuição de dados desprovidos de mecanismos de interatividade, de criação colaborativa e de aprendizagem construída (SILVA, 2008, p. 69).

Com base neste cenário delineado por Silva (2008), cabe ressaltar que também existem discussões sobre a educação online, uma forma diferente de educação ainda não referendada pelos documentos legais da educação como modalidade de ensino, mas que já vem sendo investigada por alguns autores, a exemplo de Santos (2005), ao afirmar que se trata de um modelo educativo que apresenta nuances específicas na efetivação da prática, tendo em vista que demanda uma quebra de paradigmas na educação e uma mudança de postura governamental, mas pode ser, daqui a algum tempo, um caminho fecundo para a educação.

[...] a educação online vive uma grandiosa oportunidade com o computador online que oferece disposições técnicas que contemplam a expressão de fundamentos essenciais da educação como diálogo, compartilhamento de informações e de opiniões, participação, autoria criativa e colaborativa (SILVA, 2008, p. 7I).

Novos tempos pedem novas formas de ensino e, no contexto da cibercultura, notadamente marcado pela comunicação em rede, através das tecnologias digitais, a educação online pode ser trabalhada em diferentes instituições de ensino, principalmente de ensino superior. No momento, algumas experiências mostram que ela tende a ser mais efetiva para aqueles estudantes que já possuem um desempenho mais alto, a exemplo de alunos de nível superior (AHN; MCEACHIN, 2017).

É importante ressaltar que, devido ao fato de a educação online fazer uso de diferentes interfaces, assim como a educação a distância faz uso de ambientes virtuais de aprendizagem com suas interfaces específicas, ela acaba sendo abordada na literatura especializada em educação e tecnologias como uma evolução das gerações da EaD, porém, de acordo com Santos (2005, p. 106), “[...] a educação online não é apenas uma evolução das gerações da EaD, mas um fenômeno da cibercultura", isto é, uma maneira diferente de fazer educação, aproveitando todas as possibilidades oferecidas pela cibercultura, mas diferenciando-se em muito da EaD principalmente por oferecer ao aprendente oportunidades de participar colaborativamente na construção do conhecimento. A educação online é, nesse sentido, “o 
conjunto de ações de ensino-aprendizagem desenvolvido por meio de meios telemáticos, como a videoconferência e a teleconferência" (MORAN, 2003, p. 40).

Nós compreendemos por educação online, a modalidade educacional que se caracteriza por processos de ensino e de aprendizagem que acontecem totalmente em rede, por meio da comunicação multidirecional possibilitada pelo sinal digital e viabilizada por diferentes TD. Na educação online o foco está na interação, na autoria e co-construção do conhecimento, favorecendo a aprendizagem colaborativa. $O$ foco não está nem no conteúdo, nem no sujeito, mas na relação dialógica que se estabelece entre todos os atores humanos (estudantes, professor, tutor) mediada pelas TD e viabilizadas tanto por meio da comunicação síncrona, quanto assíncrona é privilegiada. O modelo pedagógico, por estar perpassado pela lógica de rede, é predominantemente interacionista, possibilitando a conexão, a liberação do polo de emissão, e, consequentemente, instigando a reconfiguração de currículos, metodologias e práticas pedagógicas, provocando uma mudança de paradigma (SCHLEMMER; MOREIRA, 2020, p. 17-18).

O conceito de educação online trazido pelos autores é bastante esclarecedor, o que nos faz perceber a diferença existente entre educação a distância e educação online. Se a primeira é marcada pela falta de colaboração ativa, na segunda, o processo de colaboração é fundante para que a aprendizagem aconteça. Além disso, a interatividade é marca registrada da educação online, uma educação todos-todos, isto é, permite que todos ensinem ao passo que aprendem. Assim, mesmo que o aluno participe de determinada atividade dando uma opinião (como nos fóruns da $\mathrm{EaD}$ ), não há interatividade, que diz respeito à co-criação de uma mensagem, ou seja, a intervenção física de cada sujeito na mesma mensagem, ampliando-a, modificando-a ou melhorando-a.

É preciso que o sujeito interaja com a mensagem e que faça interferência nela para contribuir com o processo comunicativo. Nesse viés, podemos visualizar alguns princípios da interatividade existente na educação online:

Os princípios da interatividade podem ser encontrados em sua complexidade nas disposições técnicas do computador online. São três basicamente: a) participaçãointervenção: participar não é apenas responder "sim" ou "não" ou escolher uma opção dada, supõe interferir no conteúdo da informação ou modificar a mensagem; b) bidirecionalidade-hibridação: a comunicação é produção conjunta da emissão e da recepção, é co-criação, os dois polos codificam e decodificam; c) permutabilidadepotencialidade: a comunicação supõe múltiplas redes articulatórias de conexões e liberdade de trocas, associações e significações (SILVA, 2008, p. 70).

Dessa maneira, fica claro o quanto muda o contexto de comunicação em tempos de cibercultura, um contexto que pede mais ação por parte do sujeito, que requer dele diferentes habilidades comunicativas para produzir diferentes tipos de mensagens e para viver nesse mundo cuja comunicação acontece em rede. 
Possibilidades e desafios no trabalho docente em tempos de pandemia: uma experiência significativa...

\section{A prática do ensino remoto na Faculdade do Nordeste da Bahia}

Para levarmos adiante esta pesquisa, contamos com a pesquisa bibliográfica, a partir da revisão da literatura e com a pesquisa online. Segundo Freitas et al. (2004), esse tipo de pesquisa se mostra importante porque oportuniza ao pesquisador utilizar recursos não utilizáveis em uma pesquisa convencional/presencial, pois a aplicação do questionário seria bastante diferente. Ademais, em relação ao respondente, a pesquisa online é mais conveniente, pois ele pode responder sem a pressão do pesquisador, o qual, por sua vez, não precisa se deslocar, como faz na pesquisa in loco.

Optamos pela abordagem qualitativa, a fim de mostrarmos como a educação tem acontecido na instituição alvo da pesquisa na pandemia. A escolha da abordagem qualitativa se deu porque essa abordagem de pesquisa "preocupa-se [...] com aspectos da realidade que não podem ser quantificados, centrando-se na compreensão e explicação da dinâmica das relações sociais" (GERHARDT; SILVEIRA, 2009, p. 32).

Quanto à técnica de coleta de dados, adotamos o questionário online, através da ferramenta Google Forms. Segundo Gil (1999, p. 128), a técnica de coleta de dados pode ser definida "como a técnica de investigação composta por um número mais ou menos elevado de questões apresentadas por escrito às pessoas, objetivando o conhecimento de opiniões, crenças, sentimentos, interesses, expectativas e situações vivenciadas". Nesse caso, fazemos o uso do Google Forms, um aplicativo gratuito que integra o pacote do $G$ Suite For Education. Ele permite que o pesquisador crie formulários online para acompanhar pesquisas, criando questões discursivas e/ou de múltipla escolha, de modo que o pesquisador economizará tempo na distribuição e recolhida dos questionários, além de alcançar um número maior de pessoas.

O contexto desta pesquisa é a Faculdade do Nordeste da Bahia -instituição privada de ensino, localizada na cidade de Coronel João Sá - BA, e contou com II professores do curso de Pedagogia. Os docentes participaram de uma dinâmica elaborada pela coordenadora do curso, respondendo a três questões, e também responderam a um questionário disponível no Google Forms, cujo propósito, tanto da dinâmica quanto do questionário, era saber como eles estavam encarando trabalhar remotamente e quais os maiores desafios enfrentados. A pesquisa ocorreu de 26 de março a 10 de junho de 2020 .

No dia 17 de março de 2020, foi apresentado o primeiro decreto que anunciava a suspensão das aulas presenciais. Desse modo, as primeiras semanas geraram um sentimento de angústia, de insegurança e de dúvidas, surgindo, assim, muitas perguntas sem respostas.Vale lembrar que a instituição não tinha uma plataforma definida, mas a continuidade das atividades se deu via Skipe, Zoom, WhatsApp, Padlet, Podcast, entre outros.

Contamos com II professores no curso de Pedagogia e, devido ao fato de todos os docentes já terem feito o seu Plano Individual de Trabalho - PIT, tiveram que modificá-lo, para incluir as aulas 
remotas que seriam trabalhadas a partir daquele momento.

Assim, o novo cenário instigou a necessidade de se repensar o planejamento e desenvolvimento das atividades, levando-nos a desbravar com intensidade o ambiente online para conseguir encontrar tecnologias digitais diversas que pudessem nos auxiliar na continuação dos trabalhos, algo que acabou gerando impactos positivos e negativos.

No primeiro encontro, realizado algumas semanas depois da suspensão das aulas presenciais pela coordenadora do curso de Pedagogia-FANEB, que também faz parte do corpo docente da instituição, foi discutido a respeito da continuação das aulas à luz do ensino remoto no referido curso, que já estava acontecendo desde a suspensão. No encontro, ocorreu uma dinâmica de perguntas, através das quais pudemos analisar as primeiras impressões dos docentes presentes nessa reunião virtual via Skype acerca da continuação das aulas com o ensino remoto.

Contamos com as composições das respostas com a primeira pergunta da dinâmica: "O que está sendo bom?". A pergunta é simples, porém, a dinâmica nos proporciona, em pouco tempo, avaliar - que os professores estão vivenciando diante do seu contexto de trabalho no ensino remoto emergencial ${ }^{10}$. Segue o Quadro I:

Quadro I- Dinâmica "O que está sendo bom?"

\begin{tabular}{|c|c|}
\hline Professores & O que está sendo bom? \\
\hline $\mathrm{PI}$ & $\begin{array}{l}\text { Trabalhar a aula no WhatsApp; } \\
\text { Gravar vídeo de interação. }\end{array}$ \\
\hline P2 & A exigência das alunas. \\
\hline P3 & Avaliar e ajustar as práticas do momento. \\
\hline P4 & $\begin{array}{l}\text { Que estou revendo minhas práticas tanto na docência e também as ações } \\
\text { na coordenação pedagógica. }\end{array}$ \\
\hline P5 & $\begin{array}{l}\text { Quanto ao trabalho remoto, a vantagem é que estou reinventando } \\
\text { (aprendendo com a tecnologia e tentando explorar de forma eficiente } \\
\text { esse recurso), mas confesso que nada substitui um professor em sala de } \\
\text { aula. }\end{array}$ \\
\hline P6 & $\begin{array}{l}\text { Do compromisso demonstrado pela maior parte dos alunos, que têm } \\
\text { sido atentos aos prazos estabelecidos, salvo algumas exceções. A } \\
\text { autonomia é outro ponto que quero destacar. Apesar de não ser a forma } \\
\text { ideal de aula - a aula remota -, isso faz com que o aluno saia da zona de } \\
\text { conforto, de querer receber tudo pronto. Nesse momento, ele precisa } \\
\text { receber as orientações e "se virar", mostrando um mínimo de } \\
\text { compromisso e organização. Creio que isso fará bem a eles quando esse } \\
\text { momento passar. }\end{array}$ \\
\hline P7 & $\begin{array}{l}\text { Ver que alunos que em sala são mais introspectivos e por isso não } \\
\text { participam tão ativamente das discussões estão sendo bem participativos } \\
\text { nos debates no grupo de WhatsApp, fazendo inclusive um link do } \\
\text { trabalhado com sua vivência. }\end{array}$ \\
\hline
\end{tabular}

${ }^{10}$ Neste quadro, contamos com 8 de II professores que compõem o curso de Pedagogia da instituição, devido ao fato de, no dia do encontro, apenas estes estarem participando. 
Possibilidades e desafios no trabalho docente em tempos de pandemia: uma experiência significativa...

P8

Perceber que a maioria dos alunos permanece motivada, que se manifestam e participam dos fóruns criados para discussão, sobretudo alunos que, geralmente, não participam em sala de aula.

Fonte: Dados da Pesquisa - Respostas dos Docentes do Curso de Pedagogia/FANEB, 2020.

Podemos compreender, à luz das respostas dos docentes, uma preocupação na composição das metodologias aplicadas para esse momento do ensino remoto, demonstrada pelos aplicativos e ferramentas utilizados, bem como a busca de novos posicionamentos perante a função docente. Ou seja, notamos um olhar profissional por parte dos docentes que, mesmo diante das adversidades impostas pela pandemia, buscam qualificar-se no uso de tecnologias digitais para atender aos alunos, mesmo enfrentando dificuldades. "O formador forma-se a si próprio, através de uma reflexão sobre os seus percursos pessoais e profissionais (autoformação); o formador forma-se na relação com os outros, numa aprendizagem conjunta que faz apelo à consciência, aos sentimentos e às emoções [...]" (NÓVOA, 2004, p. 16).

Nessa ótica, diante das necessidades que se apresentaram, o corpo docente da FANEB precisou refletir acerca de sua formação e da urgência de fazer uso das tecnologias digitais para continuar os trabalhos, não apenas pensando em si mesmo, mas também no outro - o aluno, principalmente porque, dadas as circunstâncias, os alunos estavam com seus sentimentos e emoções abalados, cogitando desistência da faculdade. Assim, a postura acolhedora dos professores e sua preparação/autoformação através do uso de tecnologias digitais variadas, de diferentes formas, conseguiu passar confiança para os alunos e fazê-los permanecer no curso. Inclusive, os professores aprenderam muito com os alunos sobre tecnologias digitais, confirmando a afirmação de Freire (1996) de que aquele que ensina, aprende ao ensinar, ao passo que aquele que aprende, ensina ao aprender.

Outro ponto apresentado nas narrações de alguns docentes diz respeito à postura dos discentes. Sabemos que eles escolheram a modalidade presencial, mas a pandemia nos direcionou ao distanciamento geográfico, fazendo com que experimentássemos outras possibilidades de aprendizagem. $O$ distanciamento passou a exigir dos alunos autonomia, além do compartilhamento junto com seus colegas e docentes, mostrando que, mesmo no espaço virtual, eles podem aprender e construir conhecimento.

O conceito de autonomia do aluno significa que os alunos têm capacidades diferentes para tomar decisões a respeito do seu próprio aprendizado. A capacidade de um aluno para desenvolver um plano de aprendizado pessoal, a capacidade para encontrar recursos para o estudo em seu próprio ambiente comunitário ou de trabalho e a capacidade para decidir sozinho [...] (MOORE; KEARSLEY, 2008, p. 245).

Nesse contexto, professor e alunos, de diferentes formas, saíram beneficiados com um ensino centrado nas tecnologias digitais, objetivando utilizar tais recursos como elemento formativo e 
construtor de conhecimentos.

O Quadro 2,“O que não está sendo bom?”, corresponde aos desafios enfrentados e percebidos no momento do isolamento físico, em que se sobressaem os aspectos negativos identificados pelos professores.

Quadro 2- Dinâmica "O que não está sendo bom?"

\begin{tabular}{|c|l|}
\hline Professores & \multicolumn{1}{|c|}{ O que não está sendo bom? } \\
\hline PI & Falta de acesso para alguns. \\
\hline P2 & Falta de condições. \\
\hline P3 & Que não temos o retorno de alguns alunos. \\
\hline P4 & $\begin{array}{l}\text { A desigualdade econômica e social e do acesso à internet que se faz } \\
\text { ainda presente no nosso contexto. }\end{array}$ \\
\hline P5 & $\begin{array}{l}\text { A minha dificuldade é essa prova, mas vou buscar aprender com a } \\
\text { plataforma digital a aplicação da prova. Irei somar a nota da prova com as } \\
\text { atividades já realizadas. }\end{array}$ \\
\hline P6 & $\begin{array}{l}\text { Do silêncio de alguns alunos. E não creio que o motivo seja conexão, haja } \\
\text { vista que existem alunos da sede que têm acesso à internet, mas não } \\
\text { estão participando. Penso que os alunos que estão com problemas, no } \\
\text { mínimo, deveriam entrar em contato conosco para passar sua situaçã, } \\
\text { pois não temos como saber os motivos de todos os alunos se eles não } \\
\text { sinalizarem. }\end{array}$ \\
\hline P7 & $\begin{array}{l}\text { Não ter o contato em sala de aula com os alunos, porque na sala não fico } \\
\text { quieta, ando pra lá e pra cá, interajo mais e dessa forma fico sentada na } \\
\text { cadeira o tempo todo. }\end{array}$ \\
\hline P8 & $\begin{array}{l}\text { Saber que alguns não têm acesso à internet e não têm como participar } \\
\text { das aulas e atividades remotas }\end{array}$ \\
\hline &
\end{tabular}

Fonte: Dados da Pesquisa - Respostas dos Docentes do Curso de Pedagogia/FANEB, 2020.

Podemos destacar que, na segunda etapa da dinâmica, foram ressaltados alguns aspectos negativos enfrentados por alguns discentes da instituição mencionada, a exemplo da desigualdade social e limitação de acesso à internet de alguns alunos que, consequentemente, acaba dificultando a comunicação direta entre os pares e entre eles e os professores. Nesse viés, podemos notar que o maior entrave destacado pelos alunos - a questão do acesso, é um problema frequente nas instituições de ensino brasileiras. A exclusão digital é parte de uma exclusão maior - a social, tão discutida por teóricos como Silveira (200I), Santos (2009) e Knop (2017). Por isso, compreender as condições dos alunos e as adversidades que eles enfrentam nas questões mais básicas é mais um desafio para o professor.

Já a terceira pergunta, “O que você sugere para melhoria?", tem a finalidade de provocar as sugestões dos participantes quanto ao panorama relatado acerca dos aspectos negativos e possibilidades de melhorá-los a partir do replanejamento e redefinição das mediações pedagógicas para dar prosseguimento ao período acadêmico. 
Possibilidades e desafios no trabalho docente em tempos de pandemia: uma experiência significativa...

Quadro 3- Dinâmica "O que você sugere para melhoria?"

\begin{tabular}{|c|l|}
\hline Docentes & \multicolumn{1}{|c|}{ O que você sugere para melhoria? } \\
\hline PI & Buscar utilizar a melhor forma com a tecnologia. \\
\hline P2 & Continuar a interação \\
\hline P3 & Rever as práticas \\
\hline P4 & $\begin{array}{l}\text { Não ficarmos como os comuns. Aproveitar o máximo essa oportunidade, } \\
\text { o ensino remoto, para a provocação, interação, invenção e criatividade. }\end{array}$ \\
\hline P6 & $\begin{array}{l}\text { Pra mim está sendo muito desafiador, tenho muitas dificuldades, mas } \\
\text { tentando superá-las da melhor forma possível. Ensinar estatística a } \\
\text { distância é uma tarefa árdua. }\end{array}$ \\
\hline $\begin{array}{l}\text { Que mesclemos cada vez mais nossas aulas, principalmente a avaliação, } \\
\text { tendo em vista o momento atípico. Uma colega, ontem, mencionou a } \\
\text { prova com consulta - acho legal e eficaz, e sugiro também uma avaliação } \\
\text { oral. Estou pensando em pedir aos alunos para gravarem um vídeo de até } \\
5 \text { minutos, tentando explicar o que eles compreenderam dos conteúdos } \\
\text { até o momento, como uma das notas. Com essa avaliação, vou poder } \\
\text { analisar o domínio do conteúdo (mas eles podem usar anotações como } \\
\text { apoio), postura, oralidade, vocabulário etc. Nesse tipo de avaliação, eles } \\
\text { também precisam exercitar o poder de síntese, para escolher, dentre } \\
\text { tudo o que foi visto, as partes que merecem mais atenção. }\end{array}$ \\
\hline P7 & $\begin{array}{l}\text { O que sentia falta era dessa contribuição do grupo de professores, pois, } \\
\text { como cheguei há pouco, o meu contato era apenas com a coordenadora, } \\
\text { que me dá um excelente suporte, mas gosto de troca de ideais e esse } \\
\text { grupo e a reunião pra mim foram essenciais. Então o meu que tal já foi } \\
\text { feito. }\end{array}$ \\
\hline $\begin{array}{l}\text { Após passar essa pandemia, continuarmos com algumas atividades extras } \\
\text { voltadas para as tecnologias e web aulas para que os nossos alunos } \\
\text { despertem ainda mais o interesse pela inovação educacional. Afinal, o } \\
\text { ensino híbrido tem sido uma realidade. }\end{array}$ \\
\hline
\end{tabular}

Fonte: Respostas dos Docentes do Curso de Pedagogia/FANEB, 2020.

Ressaltamos que os docentes sinalizam a importância da presença do ensino híbrido e da consciência de que, após a pandemia, não seremos os mesmos professores diante das práticas presenciais de ensino. Muito do que tem sido usado no ensino remoto certamente poderá ser usado de forma híbrida para facilitar o processo de ensino-aprendizagem dos alunos.

De acordo com Horn e Staker (2015), o ensino híbrido pode ser compreendido como um programa educacional constituído por uma parte presencial e outra online, no qual o estudante tem a possibilidade de adequar tempo e espaço para fins de aprendizagem no seu próprio ritmo e espaço. Trata-se de uma forma de ensino bastante apropriada para a contemporaneidade, principalmente por fazer uso das tecnologias digitais contextualizadas ao ensino e favorecer o protagonismo estudantil.Ao destacar a possibilidade do ensino híbrido posteriormente, os docentes mostram que entendem a 
emergência deste tipo de ensino.

Nesse período, contamos também com a presença do Google Meet.A sala virtual proporcionou melhores condições para o ensino remoto, devido a essa ferramenta nos oportunizar um planejamento e uma organização mais eficazes, além de nos manter o mais próximo possível dos nossos alunos, mesmo à distância.

A Figura I traduz a nossa experiência representada em cinco balões, que não se resume somente a esses pontos, mas é um ciclo da Representatividade Pedagógica que tem persistido em nosso contexto.

Figura I- Ciclo da Representatividade Pedagógica

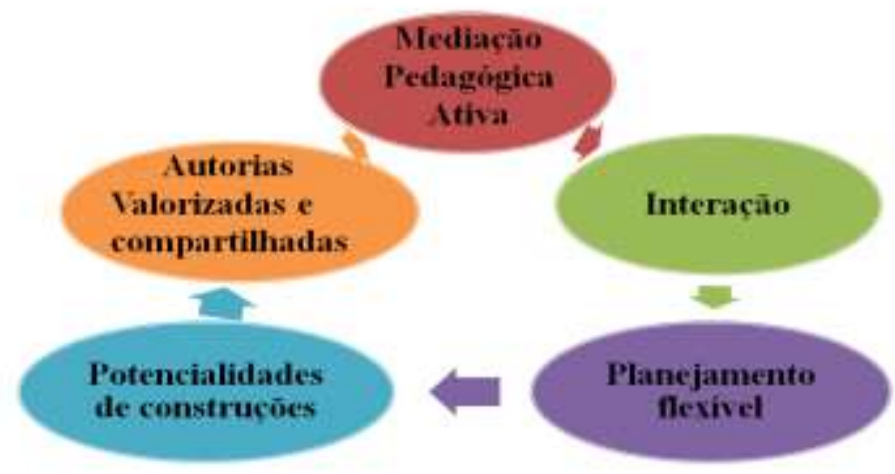

Fonte: Elaborado com base no artigo, disponível em: http://www.uff.br/revistaedufoco/files/2013/05/artigo-5.pdf

Dessa forma, o prosseguimento que temos organizado perpassa a mediação pedagógica ativa, pois os docentes têm buscado o atendimento para além do dia da aula remota. Com isso, a interseção tem permitido o ganho da interação entre professores, alunos e coordenação. São perceptíveis as potencialidades de construções neste momento, a exemplo de materiais didáticos criados pelos professores para compor suas aulas remotas (gravação de vídeos e podcasts). Os alunos seguem na mesma trilha dos seus professores, apresentando diferentes produções nessa caminhada virtual através das TDIC.

Destacamos que professores e alunos têm interagido em diferentes redes sociais, realizando inscrição no YouTube, Instagram, Facebook e organizando lives entre os professores de todos os cursos da instituição e público externo, promovendo também encontros fora da hora da aula.

Sobre as autorias, visitando o Instagram da instituição 'I, principalmente dos dias 18 a 23 de maio de 2020, é possível verificar as autorias e os compartilhamentos de vídeos contextualizando a "Semana

I Disponível em: https://instagram.com/faneb_cjs?igshid=lihcqbd4hgmll. Acesso em: 25 maio 2020. 
Possibilidades e desafios no trabalho docente em tempos de pandemia: uma experiência significativa...

do Pedagogo", que aconteceu também em outras plataformas, constituindo, dessa forma, uma rede colaborativa de trocas de saberes e conhecimentos e espaço de valorização e de construção coletiva. Fica evidente, nesse contexto, a importância da colaboração no processo de ensino-aprendizagem.

A aprendizagem colaborativa e a aprendizagem cooperativa têm sido frequentemente defendidas no meio acadêmico atual, pois se reconhece nessas metodologias o potencial de promover uma aprendizagem mais ativa por meio do estímulo: ao pensamento crítico; ao desenvolvimento de capacidades de interação, negociação de informações e resolução de problemas (TORRES; IRALA, 20I4, p. 6I).

A pandemia fez com que a Faculdade do Nordeste da Bahia recorresse ao ensino remoto, de modo a sempre conscientizar e alertar a comunidade acadêmica de que estamos trabalhando com ensino remoto e não com educação à distância - EaD. Sabemos que o ensino remoto se assemelha à $\mathrm{EaD}$ apenas no que se refere a uma educação mediada pela tecnologia, mas sua forma é totalmente distinta, como já foi salientado na parte teórica deste trabalho, especialmente por Schlemmer e Moreira (2020).

Para compor as futuras projeções das vivências e experiências do que aprendemos e o que ainda podemos realizar, contamos com o aplicativo Google Forms para realizar a pesquisa, que traz novas percepções dos docentes no contexto pandêmico. Dessa forma, a Figura 2 apresenta um gráfico correspondente à tecnologia mais utilizada pelos docentes.

Figura 2: Primeira pergunta no Google Forms

\section{1) Quais as tecnologias (Midias sociais, plataformas entre outros) foram utilizadas para compor suas aulas durante o ensino remoto?}

11 respostas

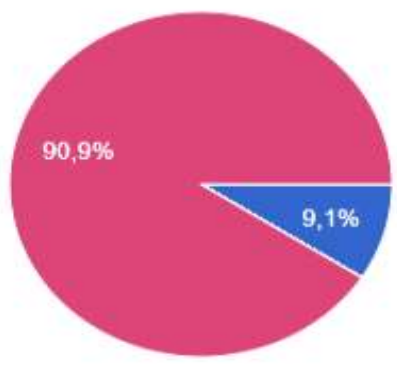

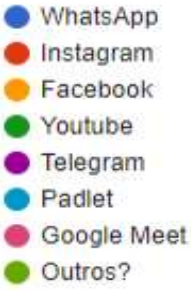

Outros?

Fonte: Dados da Pesquisa - Respostas dos Docentes do Curso de Pedagogia/FANEB, 2020.

Podemos notar, a partir do Gráfico 2, que o Google Meet foi o mais sinalizado, expressando uma aceitação à plataforma adotada pela instituição, mas tivemos a indicação do aplicativo WhatsApp como 
Jose Batista de Souza, Daniele Santana de Melo e Suely Cristina Silva Souza

uma ferramenta bastante utilizada na comunicação professor/aluno. De forma semelhante, uma pesquisa realizada recentemente por Souza et al. (2020) revelou que, de uma série de tecnologias utilizadas pelos professores no curso de Ciências Contábeis da Universidade Federal do Ceará, 60\% dos alunos apontaram o Google Meet como a ferramenta de sua preferência, destacando-se também ○ Whatsapp com $20 \%$ da preferência.

A aceitação maior dos alunos pelo Google Meet pode se dar por se tratar de uma ferramenta que possibilita o ensino síncrono, no qual professores e alunos podem se ver, alunos podem interagir quando quiserem, além de o aluno interagir pelo chat, no caso dos mais tímidos.

O Quadro 4 corresponde à segunda pergunta, que indaga os docentes sobre os maiores desafios enfrentados no momento.

Quadro 4- Perguntas e respostas Google Forms

\begin{tabular}{|c|c|}
\hline $\begin{array}{l}\text { PERGUNTA } \\
\text { 2-Quais os maiores desafios você tem } \\
\text { enfrentado nesse período? }\end{array}$ & RESPOSTAS \\
\hline \multirow{11}{*}{$\begin{array}{l}\text { 2-Quais os maiores desafios você tem } \\
\text { enfrentado nesse período? }\end{array}$} & P I Ensino Remoto \\
\hline & P2 Ausência de alunos \\
\hline & P3 Adaptação as tecnologias e qualidade ruim da internet \\
\hline & P4 Dificuldade de acesso à internet de alguns discentes \\
\hline & P5 Adaptação ao ensino remoto \\
\hline & $\begin{array}{l}\text { P6 Aprender a lidar com diferentes ferramentas digitais para } \\
\text { continuar ministrando aulas eficazes para os alunos. }\end{array}$ \\
\hline & P7 A dificuldade de acesso à internet dos alunos. \\
\hline & P8 Dificuldade de acessibilidade a internet por parte dos alunos. \\
\hline & $\begin{array}{l}\text { P9 Velocidade de internet em dia de chuva e conquistar uma parte } \\
\text { dos alunos para participarem. }\end{array}$ \\
\hline & $\begin{array}{l}\text { P I0 Adaptar as aulas para o formato de vídeo aula e a demanda } \\
\text { por aprender a utilizar as ferramentas tecnológicas. }\end{array}$ \\
\hline & P I I As dificuldades dos alunos em participarem do Google Meet. \\
\hline
\end{tabular}

Fonte: Dados da Pesquisa - Respostas dos Docentes do Curso de Pedagogia/FANEB, 2020.

As repostas continuam sinalizando o problema de acesso à internet e a ausência de alguns alunos, que demonstram não se sentirem confortáveis com ensino remoto e até a dificuldade em usar as TDIC.

Em seguida, no Quadro 5, trazemos a terceira pergunta, que busca saber dos professores quais TDIC utilizadas atualmente que eles pretendem continuar utilizando após a pandemia.

Quadro 5- Perguntas e respostas Google Forms

\begin{tabular}{|l|l|}
\hline \multicolumn{1}{|c|}{ PERGUNTA } & \multicolumn{1}{c|}{ RESPOSTAS } \\
\hline 3-Você pretende continuar utilizando quais dessas & PI Google Meet e outros. \\
\cline { 2 - 2 } tecnologias nas suas aulas pós pandemia? Por quê?? & P2 Watz, insta, meet e outros... porque facilita a \\
(Whatsapp/ Instagram/ Facebook/ YouTube & $\begin{array}{l}\text { comunicação, interação e o ensino híbrido a partir de } \\
\text { agora vai fazer parte do cotidiano educacional. }\end{array}$ \\
\cline { 2 - 2 } Telegram/ Padlet/ Google Meet e/ou outros) & $\begin{array}{l}\text { P3 Whatsapp, Instagram e Google Meet. Porque tanto } \\
\text { eu como meus alunos estamos conseguindo nos }\end{array}$ \\
\hline
\end{tabular}

Olhar de professor, Ponta Grossa, v. 24, p. I-25, e-I5952.04I, 202 I.

Disponível em <https://revistas2.uepg.br/index.php/olhardeprofessor> 
Possibilidades e desafios no trabalho docente em tempos de pandemia: uma experiência significativa...

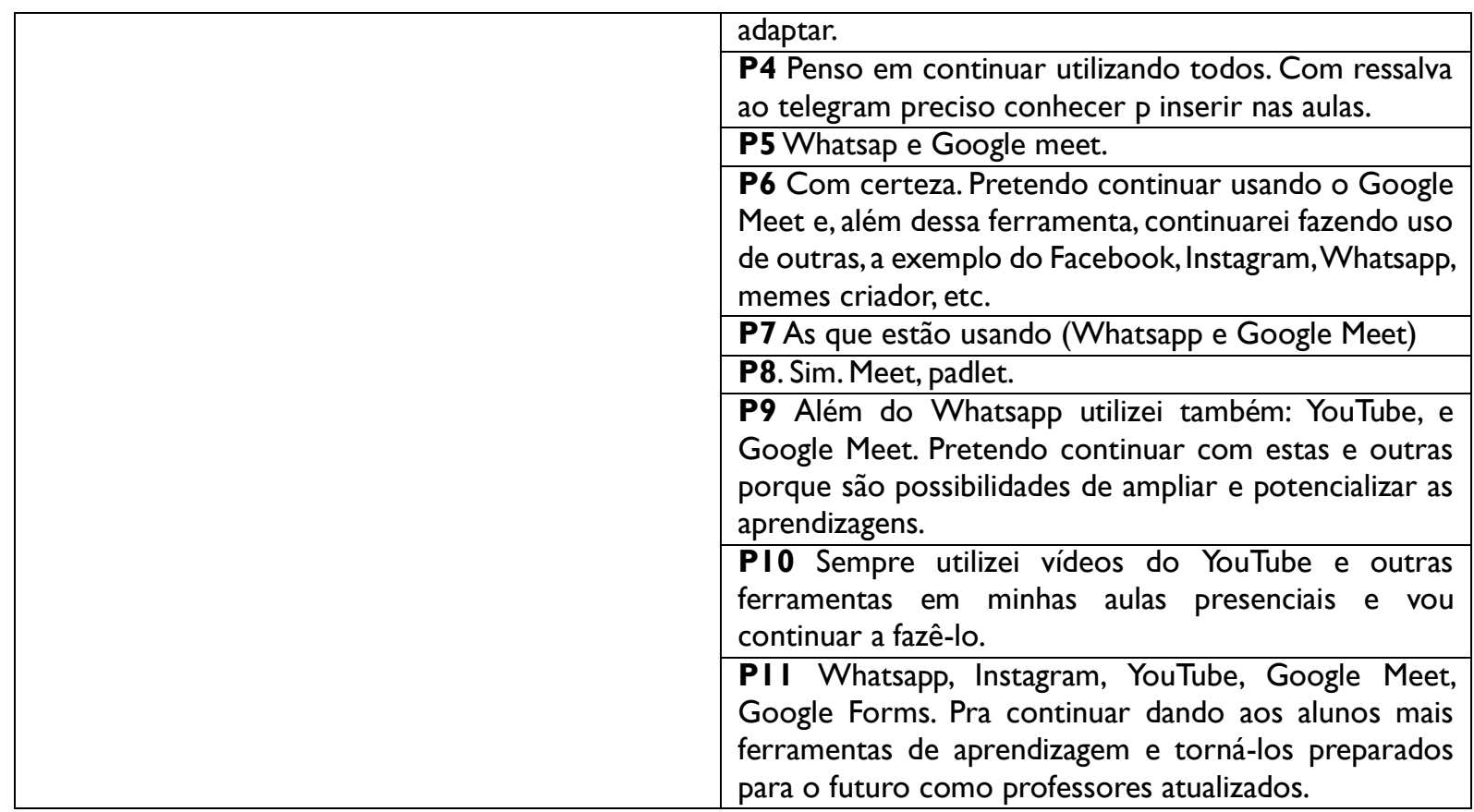

Fonte: Dados da Pesquisa - Respostas dos Docentes do Curso de Pedagogia/FANEB

Compreendemos que os retornos dos docentes foram afirmativos, pois eles informam que darão sequência ao uso, como também estão dispostos a incluírem novos aplicativos e plataformas em sua didática. Nessa conjuntura, podemos constatar que eles se sentem mobilizados a explorar ainda mais as TDIC. É interessante ressaltar que estamos ministrando aulas no ensino superior e que as metodologias trabalhadas refletem muito na ação-reflexão-ação das práticas (FREIRE, 1996) e remetem a questões relativas à formação inicial dos discentes e à formação contínua dos docentes (FREIRE, 1996;TARDIF, 2002).

O Quadro 6 apresenta dados equivalentes às percepções da participação dos discentes nessa trilha do ensino remoto.

Quadro 6- Perguntas e respostas Google Forms

\begin{tabular}{|c|c|}
\hline $\begin{array}{l}\text { PERGUNTA } \\
\text { 4- Como tem sido sua percepção acerca } \\
\text { das participações dos alunos nas aulas } \\
\text { remotas? }\end{array}$ & RESPOSTAS \\
\hline \multirow{6}{*}{$\begin{array}{l}\text { 4- Como tem sido sua percepção acerca } \\
\text { das participações dos alunos nas aulas } \\
\text { remotas? }\end{array}$} & PI Alcançamos o objetivo em quase sua totalidade. \\
\hline & P2 Os que participam são super comprometidos. \\
\hline & $\begin{array}{l}\text { P3 No início foi difícil, alguns foram resistentes, porém aos } \\
\text { poucos a participação tem aumentado. Ressalto que a qualidade } \\
\text { da internet tem sido um empecilho para alguns, sem contar que } \\
\text { alguns ficam tímidos diante das videoconferências. }\end{array}$ \\
\hline & $\begin{array}{l}\text { P4 Os discentes que estão participando assiduamente têm me } \\
\text { surpreendido a cada aula. Cada turma tem algo peculiar: uns } \\
\text { gostam mais de interagir no chat, outros utilizando o áudio, uns } \\
\text { no privado para fazer algum questionamento. }\end{array}$ \\
\hline & P5 Regular \\
\hline & $\begin{array}{l}\text { P6 A participação não tem sido tão diferente da sala de aula. Mas } \\
\text { o que tem me inquietado é a ausência constante de alguns }\end{array}$ \\
\hline
\end{tabular}

Olhar de professor, Ponta Grossa, v. 24, p. I-25, e-I5952.04I, 202 I.

Disponível em <https://revistas2.uepg.br/index.php/olhardeprofessor> 


\begin{tabular}{|l|l|}
\hline \multirow{5}{*}{} & alunos. \\
\cline { 2 - 3 } & $\begin{array}{l}\text { P7 Alguns que eram mais introspectivos na sala de aula acabam } \\
\text { participando mais na modalidade remota. }\end{array}$ \\
\hline $\begin{array}{l}\text { P8 Falta de mais esforço, comprometimento por parte de quem } \\
\text { tem acesso. Daqueles que participam das aulas, estes são } \\
\text { participativos e interagem com colegas e professor. }\end{array}$ \\
\hline $\begin{array}{l}\text { P9 Positiva e desafiadora. Os alunos vêm se desafiando e } \\
\text { buscando aprender. Se usamos o Whatsapp percebo que eles } \\
\text { entendem bem que é uma ação emergencial, mas utilizar o } \\
\text { Google Meet, além de ser uma plataforma que mais exclui nosso } \\
\text { público-alvo, também causa certa confusão no tipo de } \\
\text { modalidade de seu curso. Tudo isso é percepção sem se basear } \\
\text { em dados. Uma pesquisa faz-se necessária. Por isso, nós do } \\
\text { PAIDÉlA - Grupo de Estudos e Pesquisas em Educação da } \\
\text { FANEB estamos planejando uma pesquisa para elucidar tal } \\
\text { momento. }\end{array}$ \\
\hline $\begin{array}{l}\text { PIO Os alunos têm participado quase que efetivamente, mas há } \\
\text { muitas reclamações acerca da oscilação da internet que muitas } \\
\text { vezes eles acabam não ficando até o final das aulas. }\end{array}$ \\
\hline $\begin{array}{l}\text { PI I Os alunos mostraram muita responsabilidade e dedicação } \\
\text { nas aulas e atividades. }\end{array}$ \\
\hline
\end{tabular}

Fonte: Respostas dos Docentes do Curso de Pedagogia/FANEB

Verificamos, frente a todo o contexto analisado, a relevância da participação ativa no processo do ensino remoto, pois a composição da qualidade educacional equivale à comunicação direta do professor e do aluno, visto que a autoavaliação e o feedback de ambos é o que possibilita a aprendizagem e o alcance dos objetivos propostos. Além disso, a participação do aluno é fundamental para a conquista de sua autonomia (FREIRE, 1996).

O conjunto das respostas apresentadas colaborou para revelar um diagnóstico do curso de Pedagogia da FANEB diante da pandemia. Cada turma, junto com seus professores, traz um retrato diferente. E é bom que seja diferente, pois somos plurais e a força do trabalho coletivo e colaborativo tem feito a diferença do nosso contexto educacional.

\section{Considerações finais}

Neste trabalho, nos propusemos a mostrar como a Faculdade do Nordeste da Bahia tem se reinventado para levar adiante seu trabalho e continuar promovendo ensino e aprendizagem aos seus alunos em uma perspectiva qualitativa - missão maior de toda instituição que se propõe a trabalhar com educação. Para tal, trouxemos um panorama de como o mundo se encontra neste momento marcado pela pandemia da Covid-19, mostrando como ela tem impactado em todos os setores da sociedade, a exemplo do setor educacional.

A partir de dados colhidos junto a diversos veículos de comunicação e órgãos que se dedicam a pesquisar a educação, a exemplo do Todos pela Educação (2020), bem como de um aporte teórico 
Possibilidades e desafios no trabalho docente em tempos de pandemia: uma experiência significativa...

norteador e que concede sustentação científica às evidências do estudo, tentamos demonstrar o contexto no qual todos estamos imersos e as possibilidades que têm se apresentado para que possamos seguir em frente.

Diante do contexto apresentado, e mediante a apropriação de subsídios teóricos, emergiram no bojo das discussões os tópicos educação a distância, ensino remoto e educação online, conceituandoos e mostrando as especificidades de cada um, esclarecendo que, apesar de acontecer a distância, o ensino remoto não é educação a distância, pois as metodologias e o desenho didático-pedagógico são totalmente diferentes, tendo em comum apenas o uso das tecnologias digitais.

Por último, contextualizamos a pesquisa, apresentando o contexto investigado - a Faculdade do Nordeste da Bahia, e tudo o que aconteceu no processo de ensino-aprendizagem nesse período de pandemia. $\mathrm{Na}$ contextualização, apresentamos, a partir da análise de uma dinâmica e de um questionário aplicado aos professores do curso de Pedagogia, os resultados de seu trabalho com o ensino remoto, concluindo que, apesar das dificuldades que professores e alunos têm enfrentado, a exemplo da conexão com a internet, as aulas têm fluído e contribuído em um processo de ensino direcionado à aprendizagem discente, mesmo em um contexto desafiador para todos os envolvidos no processo.

Portanto, diante de todo o cenário teórico e metodológico apresentado, os resultados preliminares apontam que, por mais que as dificuldades de acesso à internet tenham se destacado, principalmente nos primeiros meses, os entraves foram diminuindo ao longo do tempo.Além disso, os equívocos por parte dos alunos em relação à educação a distância e ensino remoto, que se destacaram no início, inclusive levando alguns alunos a pensarem em trancar o curso, com o tempo foi evidenciando a questão adaptativa ao ensino remoto, em decorrência da conjuntura contemporânea, o que trouxe para alunos e professores uma segurança maior para seguir com esse tipo de ensino.

\section{Referências}

AHN, J.; MCEACHIN, A. Student Enrollment Patterns and Achievement in Ohio's Online Charter Schools. Educational Researcher, Florida, v. 46, n. I, p. 44-57, 2017.

ARAÚJO, A. M. de; MATTOS, C. L. G. de. Exclusão digital e educação: a infraestrutura como condição primária. e-Mosaicos - Revista Multidisciplinar de Ensino, Pesquisa, Extensão e Cultura do Instituto de Aplicação Fernando Rodrigues da Silveira, Rio de Janeiro, v. 7, n. 16, p. 157-180, dez. 2018.

ARAÚJO, W. Educação: Confira algumas das universidades públicas que já adotaram o ensino remoto. Notícias Concursos - Educação. Disponível em:

https://noticiasconcursos.com.br/educacao/educacao-confira-algumas-universidades-publicas-queadotaram-o-ensino-remoto/. Acesso em: 10 out. 2020.

Olhar de professor, Ponta Grossa, v. 24, p. I-25, e-I5952.04I, 202 I.

Disponível em <https://revistas2.uepg.br/index.php/olhardeprofessor> 
BRASIL. LDB - Lei de Diretrizes e Bases da Educação Nacional. Lei $\mathbf{n}^{\circ} \mathbf{9 . 3 9 4}$, de 20 de dezembro de 1996. Estabelece as diretrizes e bases da educação nacional. 3. ed. Brasília: Senado Federal, Coordenação de Edições Técnicas, 2019.

BRASIL. Ministério da Saúde. Sobre a doença. 2020. Disponível em: https://coronavirus.saude.gov.br/sobre-a-doenca. Acesso em: 12 jun. 2020.

BRASIL. Ministério da Educação. Portaria n 343, de 17 de março de 2020. Substituição de aulas presenciais por aulas em meios digitais enquanto durar a situação de pandemia do Novo Coronavírus Covid-19. Disponível em: <http://www.in.gov.br/en/web/dou/-/portaria-n-343-de-17-de-marco-de2020-248564376 . Acesso em: 5 jun. 2020.

BRASIL. Ministério da Educação. Portaria n 345, de 19 de março de 2020. Altera a Portaria MEC $n^{\circ} 343$, de 17 de março de 2020. Disponível em: $<$ https://www.legisweb.com.br/legislacao/?id=390992 2. Acesso em: 5 jun. 2020.

CONSED. Monitoramento da suspensão de aulas. Disponível em: http://www.consed.org.br/central-de-conteudos/acompanhe-o-monitoramento-da-suspensao-dasaulas-presenciais-nas-redes-estaduais. Acesso em: 2 nov. 2020.

CRESCER ONLINE. Coronavírus: Por que o isolamento social é importante? Disponível em: https://revistacrescer.globo.com/Criancas/Saude/noticia/2020/04/coronavirus-por-que-o isolamentosocial-e-importante.html. Acesso em: 3 nov. 2020.

FACULDADE DO NORDESTE DA BAHIA. Instagram: Disponível em: https://instagram.com/faneb_cjs?igshid=lihcqbd4hgmll. Acesso em: 25 maio 2020.

FIOCRUZ. Por que a doença causada pelo novo vírus recebeu o nome de Covid-19? Disponível em: https://portal.fiocruz.br/pergunta/por-que-doenca-causada-pelo-novo-virus-recebeu-onome-de-covid-19. Acesso em: 12 nov. 2020.

FREIRE, Paulo. Pedagogia da autonomia: saberes necessários à prática educativa. São Paulo: Paz e Terra, 1996.

FREITAS, H. et al. Pesquisa via Internet: características, processo e interface. Revista Eletrônica GIANTI, Porto Alegre, p. I-I I, 2004.

GeRHARDT, T. E.; SILVEIRA, D. T. (Org.). Métodos de Pesquisa. Porto Alegre: Editora da UFRGS, 2009.

GIL, A. C. Métodos e técnicas de pesquisa social. São Paulo: Atlas, 1999.

GUEDES, Bruno Sergio Scarpa Monteiro. Gerações da Educação a Distância. Disponível em: https://siteantigo.portaleducacao.com.br/conteudo/artigos/educacao/geracoes-da-educacao-adistancia/50367. Acesso em: 25 maio 2020.

Olhar de professor, Ponta Grossa, v. 24, p. I-25, e-I5952.04I, 202 I. 
Possibilidades e desafios no trabalho docente em tempos de pandemia: uma experiência significativa...

HORN, M. B.; STAKER, H. Blended: usando a inovação disruptiva para aprimorar a educação. Porto Alegre: Penso, 2015.

KNOP, M. F. T. Exclusão digital, diferenças no acesso e uso de tecnologias de informação e comunicação: questões conceituais, metodológicas e empíricas. Caderno Eletrônico de Ciências Sociais, Vitória, v. 5, n. 2, p. 39-58, 2017.

MOORE, M. G.; KEARSLEY, G. Educação a distância: uma visão integrada. Tradução de Roberto Galman. São Paulo: Cengage Learning, 2008.

MORAN, J. M. Novas tecnologias e mediação pedagógica. Campinas: Papirus, 2003.

NAÇÕES Unidas Brasil. Internet e direitos humanos. Disponível em:

https://nacoesunidas.org/artigo-internet-direitos-humanos/. Acesso em: 3 jun. 2020.

NÓVOA, António. "Prefácio". In: Josso, M-C. Experiências de Vida e Formação. São Paulo: Cortez, 2004.

PORTAL BONDE. Pais viram professores: educação a distância impõe novos desafios às famílias. Disponível em: https://www.bonde.com.br/educacao/noticias/educacao-a-distancia-impoe-novosdesafios-as-familias-5 I4736.html. Acesso em: 2 nov. 2020.

QUEIROZ, C. Coronavírus: desafios do isolamento. Disponível em:

https://revistapesquisa.fapesp.br/desafios-do-isolamento/. Acesso em: 3 jun. 2020.

RODRIGUES, L. Conheça as $\mathbf{5}$ maiores pandemias da história. Disponível em: https://revistagalileu.globo.com/Ciencia/Saude/noticia/2020/03/conheca-5-maiores pandemias-dahistoria.html. Acesso em: 12 set. 2020.

SAMPAIO, C. Professores, pais e alunos apontam dificuldades e limitações do ensino a distância. Disponível em: https://www.brasildefato.com.br/2020/05/04/professores-pais-e-alunosapontam-dificuldades-e-limitacoes-no-ensino-a-distancia. Acesso em: 2 nov. 2020.

SANTOS, Edméa. Educação online: cibercultura e pesquisa-formação na prática docente. 2005. 35I f. Tese (Doutorado em Educação) - Universidade Federal da Bahia, Salvador, 2005.

SANTOS, Edméa. Educação online para além da EaD: um fenômeno da cibercultura. In: CONGRESSO INTERNACIONAL GALEGO_PORTUGUÊS DE PSICOPEDAGOGIA, 10., 2009, Braga. Actas [...] Braga: Universidade do Minho, 2009.

SANTOS, Edméa; ARAÚJO, Maristela Midlej. Como avaliar a aprendizagem online? Notas para inspirar o desenho didático em educação online. Educ. foco, Juiz de Fora, v. 17, n. 2, p. 103-II 9 jul. I out. 2012.

SCHLEMMER, E.; MOREIRA, J. A. Por um novo conceito e paradigma de educação digital onlife. Revista UFG, Goiânia, v. 20, p. I-35, 2020. 
Jose Batista de Souza, Daniele Santana de Melo e Suely Cristina Silva Souza

SILVA, M. Cibercultura e educação: a comunicação na sala de aula presencial e online. Revista

FAMECOS: mídia, cultura e tecnologia, v. 15, n. 37, p. 69-74, dez. 2008.

SILVEIRA, S. A. da. Exclusão Digital: a miséria na era da informação. São Paulo: Fundação Perseu Abramo, 200I.

SOUZA, J. et al. Metodologias remotas de ensino em tempos de Covid-19: estudo no curso de Ciências Contábeis da Universidade Federal do Ceará (UFC). Disponível em:

https://congressousp.fipecafi.org/anais/Anais2020/ArtigosDownload/2890.pdf. Acesso em: 20 out.

2020.

TARDIF, M. Saberes Docente e Formação Profissional. Petrópolis: Vozes, 2002.

TODOS PELA EDUCAÇÃO. Ensino a distância na educação básica frente à pandemia da

Covid-19. Disponível em:

https://www.todospelaeducacao.org.br/_uploads/_posts/425.pdf? | 730332266=. Acesso em: 20 out. 2020.

TOKARNIA, M. Um em cada 4 brasileiros não tem acesso à internet, mostra pesquisa. Disponível em: https://agenciabrasil.ebc.com.br/economia/noticia/2020-04/um-em-cada-quatro-brasileiros-naotem-acesso

internet\#: :text=A\%20Pesquisa\%20Nacional\%20por\%20Amostra,n\%C3\%A30\%20tem\%20acesso\%20 \%C3\%A0\%20internet. Acesso em: 3 nov. 2020.

TORRES, P. L.; IRALA, E. A. F. Aprendizagem colaborativa: teoria e prática. In: TORRES, P. L. (Org.). Complexidade: redes e conexões na produção do conhecimento. Curitiba: SENAR, 2014.

VALADARES, M. Coronavírus faz educação a distância esbarrar no desafio do acesso à internet e da inexperiência dos alunos. Disponível em:

https://gl .globo.com/educacao/noticia/2020/03/23/coronavirus-faz-educacao-a-distancia esbarrar-nodesafio-do-acesso-a-internet-e-da-inexperiencia-dos-alunos.ghtml. Acesso em: 20 out. 2020.

Recebido em: 13 de junho de 2020.

Versão corrigida recebida em: 18 de novembro de 2020.

Aceito em: 18 de novembro de 2020.

Publicado online em: 08 de maio de 2021 .

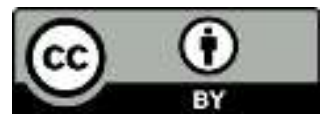

Olhar de professor, Ponta Grossa, v. 24, p. I-25, e-I5952.04I, 202 I.

Disponível em <https://revistas2.uepg.br/index.php/olhardeprofessor> 